\title{
Detection of Mycoplasma haemocanis, Mycoplasma haematoparvum, Mycoplasma suis and other vector-borne pathogens in dogs from Córdoba and Santa Fé, Argentina
}

\author{
Patricia E. Mascarelli ${ }^{1}$, Gustavo P. Tartara², Norma B. Pereyra ${ }^{2}$ and Ricardo G. Maggi ${ }^{\text {** }}$
}

\begin{abstract}
Background: In Argentina, only very few reports are available for canine tick-borne diseases where most are related to parasitic diseases. The objective of this survey was to investigate the prevalence of tick-borne pathogens in 70 dogs from Santa Fé and Córdoba, Argentina.

Methods: Microscopic blood smear examination as well as polymerase chain reaction (PCR) amplification using species-specific markers of Anaplasma, Babesia, Bartonella, Borrelia, Ehrlichia, Francisella, Mycoplasma (hemotropic group) and Rickettsia, followed by DNA sequencing were used to establish the prevalence of each infecting pathogen.

Results: Blood smear analysis showed 81\% (57/70) prevalence of structures morphologically compatible with hemotropic mycoplasmas. No structures resembling either piroplasms or Anaplasma/Ehrlichia were detected. Hemotropic mycoplasma species (Mycoplasma haematoparvum, Mycoplasma haemocanis and Mycoplasma suis) were the most prevalent pathogens detected with an overall prevalence of $77.1 \%$. Anaplasma platys was detected and identified in 11 of the 70 dogs (15.7\%), meanwhile two Bartonella spp. (B. clarridgeiae and an uncharacterized Bartonella sp.) and Babesia vogeli were detected at 3 and 7\% prevalence, respectively.

Conclusions: The work presented here describes a high molecular prevalence for hemotropic mycoplasma species in each of the five locations selected. Three Mycoplasma spp., including Mycoplasma suis, reported for the first time in dogs have been identified by DNA amplification and sequencing. This study highlights the risk that these bacterial pathogens represent for companion animals and, due to their potential zoonotic nature, also for people.
\end{abstract}

Keywords: Dogs, Babesia vogeli, Anaplasma phagocytophilum, Anaplasma platys, Ehrlichia canis, Mycoplasma haemocanis, Mycoplasma haematoparvum, Mycoplasma suis, Bartonella spp., Argentina

\footnotetext{
* Correspondence: rgmaggi@ncsu.edu

${ }^{1}$ Intracellular Pathogens Research Laboratory, Department of Clinical

Sciences, College of Veterinary Medicine, North Carolina State University,

1060 Williams Moore Dr., Raleigh, NC 27607, USA

Full list of author information is available at the end of the article
} 


\section{Background}

The detection of canine vector-borne pathogens represents a constant challenge for veterinarians and researchers. The wide array of pathogenic organisms (protozoa, bacteria and viruses), their diverse biologic behavior and distribution, and the wide spectrum of clinical signs contribute to the difficulties associated with the diagnosis of canine vector-borne diseases (CVBD).

Only few reports are available for CVBD in Argentina and, as in many countries in Latin American, most are related to parasitic diseases such as babesiosis [1, 2], hepatozoonosis [2, 3], dirofilariasis [4-7], leishmaniasis [8-15] and trypanosomiasis [8, 16-23].

The data regarding vector-borne bacterial diseases and their prevalence in dogs are scarce. Anaplasma platys, has been detected in dog blood with a prevalence ranging between $18.6 \%$ in sick animals [2] and $13.5 \%$ in feral dogs $[24,25]$. Ehrlichia canis has been recorded with a prevalence of $7 \%$ in sick dogs [2]; interestingly, a recent study performed at a clinic in Rosario, Santa Fé, showed that 76 of 100 dogs with pruritus presented structures compatible with hemotropic mycoplasmas, as determined by blood smears, and $91 \%$ of them presented varying degrees of anemia, as determined by hematocrit values and erythrocyte concentration [26]. No record of prevalence data is available for Rickettsia spp. or Bartonella spp. in Argentinian dogs.

The objective of this survey was to investigate the frequency and distribution of selected tick-borne pathogens in dogs from five locations in two provinces of Argentina. Microscopic blood smear examination as well as polymerase chain reaction (PCR) amplification using specific markers for the genera Anaplasma, Babesia, Bartonella, Ehrlichia, Mycoplasma and Rickettsia, followed by DNA sequencing were used to establish the prevalence of each infecting pathogen.

\section{Methods}

\section{Animals, study site, and sample collection}

In this study, a convenience sample of 70 dogs was tested from five locations: Isla Verde in Córdoba, $(n=24)$, San Lorenzo, Santa Fé $(n=24)$; Chañar Ladeado, Santa Fé $(n=2)$; Roldán in Santa Fé $(n=20)$; and Villa Constitución, Santa Fé $(n=4)$. Blood samples $(3 \mathrm{ml})$ were collected by venipuncture in EDTA tubes. The population consisted of male $(n=26)$ and female $(n=44)$ dogs of different breeds and various ages, ranging from 1 to 10 years. Based on behavior and gross body examination, all animals appeared healthy. No detailed clinical examinations were conducted.

\section{Microscopic examination}

Immediately after sample collection, peripheral blood smears were evaluated microscopically using MayGrünwald Giemsa method, for the presence of piroplasms
(Babesia spp. or Theileria spp.), inclusion bodies (Anaplasma spp. or Ehrlichia spp.), or small basophilic structures on erythrocytes as indication of hemotropic mycoplasma infections.

\section{DNA isolation and PCR amplification}

Genomic DNA extraction was performed using the QIAamp DNA Blood Mini kits (Qiagen, Valencia, USA) according to the manufacturer's protocol. Eight microbial genera (Anaplasma, Babesia, Bartonella, Borrelia, Ehrlichia, Francisella, Mycoplasma and Rickettsia) were targeted using specific PCR assays as previously described [27].

\section{Results}

\section{Blood smears}

Peripheral blood smear analysis showed 81\% (57/70) prevalence of structures morphologically compatible with hemotropic mycoplasmas when blood was evaluated microscopically using May-Grünwald Giemsa method. No structures resembling either piroplasms or Anaplasmal Ehrlichia were detected.

\section{Amplification and identification of vector-borne pathogens}

A total of 55 of the 70 blood DNA tested (78.6\%) were positive for at least one canine vector-borne pathogen (see Table 1).

\section{Sequencing}

In all cases in which blood samples were PCR positive, direct DNA sequencing was performed to identify pathogen species down to the level of strain when possible. Reference sequences for this study included the following GenBank accession numbers: AY055469 (Anaplasma phagocytophilum); AF399916 (Anaplasma platys); KU710803 (Babesia vogeli); AY618928 (large unnamed Babesia sp. "coco"); AF271081 (Babesia gibsoni); NC_005956.1 (Bartonella henselae Houston I); AF369529 (B. henselae SA2); DQ059763 (Bartonella vinsonii berkhoffii genotype II); DQ059764 (B. vinsonii berkhoffii genotype III); AF312490 (Bartonella koehlerae); AB896695 (Bartonella clarridgeiae); NC_007354 (Ehrlichia canis); NR_044747 (Ehrlichia ewingii); AY529641 (Mycoplasma haemocanis); GQ129113 (Mycoplasma haematoparvum); NR_103930 and AB610849 (Mycoplasma suis); and CP000848 (Rickettsia rickettsii). Sequences were compared to the GenBank database using the Basic Local Alignment Search Tool and homology data was generated using AlignX (Vector NTI suite 11.5.1, Invitrogen Inc., USA) software.

Hemotropic Mycoplasma spp. were the most prevalent pathogens detected and identified by DNA sequencing with an overall prevalence of $77.1 \%$. Anaplasma spp. was detected and identified in 11 of the 70 (15.7\%) dogs, 
Table 1 Prevalence (infected/examined) of different vector-borne pathogens in dog blood samples from Santa Fé and Córdoba, Argentina

\begin{tabular}{lllll}
\hline Location & Anaplasma spp. & Babesia spp. & Bartonella spp. & Mycoplasma spp. \\
\hline Isla Verde (Córdoba) & $3 / 24$ & $2 / 21$ & $1 / 22$ & $20 / 24$ \\
San Lorenzo (Santa Fé) & $8 / 20$ & $2 / 20$ & $0 / 20$ & $18 / 20$ \\
Roldán (Santa Fé) & $0 / 20$ & $1 / 18$ & $1 / 18$ & $13 / 20$ \\
Chañar Ladeado (Santa Fé) & $0 / 2$ & $0 / 2$ & $0 / 2$ & $1 / 2$ \\
Villa Constitución (Santa Fé) & $0 / 4$ & $0 / 4$ & $0 / 4$ & $2 / 4$ \\
Overall prevalence (\%) & $11 / 70(15.7 \%)$ & $5 / 65(7.7 \%)$ & $2 / 66(3 \%)$ & $54 / 70(77.1 \%)$ \\
\hline
\end{tabular}

meanwhile Bartonella spp. and Babesia spp. were detected in two dogs each.

The species identified at each genus and the speciesspecific prevalence are detailed in Table 2. Briefly, $M$. haematoparvum (identical with $M$. haematoparvum GQ129113; 544/544 bp) was detected at 31.4\% prevalence; $M$. haemocanis (identical with $M$. haemocanis AY529641; 537/537 bp) at 48.6\%; M. suis (identical with M. suis AB610849; 535/535 bp) at 2.9\%; B. clarridgeiae (identical with $B$. clarridgeiae AB896695; 505/505 bp) at 1.5\%; an uncharacterized Bartonella sp. (with a 552/ 582 bp homology with Bartonella tribocorum AF312505) at $1.5 \%$; B. vogeli (identical with B. vogeli KU710803; 605/ $605 \mathrm{bp}$ ) at a prevalence of $7.7 \%$, and $A$. platys (with a 77/ 79 bp homology to $A$. platys AF399916) at $15.7 \%$ prevalence.

Co-infections with two or more pathogens were also identified: M. haemocanis and M. haematoparvum were detected in $5.7 \%$ of the dogs (all from Roldán, Santa Fé); $M$. haemocanis and $A$. platys in five dogs (7.1\%), $M$. haematoparvum and $A$. platys in six dogs (8.6\%), and $M$. haemocanis and B. vogeli in two dogs (3\%). All A. platysinfected dogs were also infected with a Mycoplasma spp. (either M. haemocanis or M. haematoparvum).

No amplification of Borrelia spp., Ehrlichia spp., Francisella spp. or Rickettsia spp. DNA was obtained in any of the 70 samples tested.

\section{Discussion}

The detection of canine vector-borne pathogens represents a constant challenge for veterinarians and researchers. The wide array of vector-borne pathogens

Table 2 Prevalence (infected/examined) of Mycoplasma (hemotropic group) spp. in dog blood samples from Santa Fé and Córdoba, Argentina

\begin{tabular}{llll}
\hline Location & M. haemocanis & M. haematoparvum & M. suis \\
\hline Isla Verde (Córdoba) & $16 / 24$ & $4 / 24$ & $0 / 24$ \\
San Lorenzo (Santa Fé) & $9 / 20$ & $9 / 20$ & $0 / 20$ \\
Roldán (Santa Fé) & $7 / 20$ & $8 / 20$ & $2 / 20$ \\
Chañar Ladeado (Santa Fé) & $0 / 2$ & $1 / 2$ & $0 / 2$ \\
Villa Constitución (Santa Fé) & $2 / 4$ & $0 / 4$ & $0 / 4$ \\
\hline
\end{tabular}

(protozoans, bacteria and viruses), their diverse biological behavior and distribution, and the wide spectrum of clinical signs contribute to the difficulties associated with the diagnosis of CVBD [28, 29]. In Argentina, there are only a few reports available for canine tick-borne diseases caused by species of the genera Anaplasma, Babesia and Ehrlichia, and most of them have been limited to the state of Buenos Aires. Babesia vogeli, one of the most common etiological agents of canine babesiosis in South America, was recorded based on molecular characterisation for the first time in two dogs from Buenos Aires in 2008 [1]; A. platys, the etiological agent of granulocytic anaplasmosis and cyclic thrombocytopenia, was detected in sick and feral dogs, and E. canis, the agent of canine monocytic erhlichiosis, was also detected in feral dogs [2]. To date, no records on the detection or prevalence of Rickettsia spp., Bartonella spp. or Mycoplasma (hemotropic group) spp. are available from dogs in Argentina. The objective of this survey was to investigate the prevalence of tick-borne pathogens in dogs in five locations from two states of Argentina (Santa Fé and Córdoba). PCR amplification, aimed at genera Anaplasma, Babesia, Bartonella, Borrelia, Ehrlichia, Francisella, Mycoplasma and Rickettsia, followed by DNA sequencing was used to establish the presence of each infecting pathogen in blood collected from 70 dogs.

The prevalence of Anaplasma platys found in dogs from Córdoba (12\%) and Santa Fé (17.8\%) was similar to that previously reported for dogs from Buenos Aires (13.5-8.6\%) [2, 24, 25]. A higher prevalence of Babesia vogeli was detected in Córdoba (10\%) and Santa Fé (6.8\%) compared with a previously reported prevalence of $0.2 \%$ from Buenos Aires [1], even though the latter was estimated using blood smear analysis. No amplification of Borrelia spp., Ehrlichia spp., Francisella spp., or Rickettsia spp. DNA was obtained in any of the samples tested in the present study.

Interestingly, this is the first report on the detection and molecular identification of several Mycoplasma species from dogs from Argentina: M. haemocanis, detected in $16 / 24(66.7 \%)$ and $18 / 46(39.1 \%)$ of dogs from Córdoba and Santa Fé, respectively; $M$. haematoparvum, with a prevalence of 16.7 and 39.1\% from Córdoba and 
Santa Fé, respectively, and Mycoplasma suis detected in two dogs from Roldán. More importantly, this is the first report of the detection and amplification of Mycoplasma suis DNA from dog blood.

No statistically significant association was found ( $P$-value of 0.7226 , using a $2 \times 2$ contingency table Fisher's exact test) between blood smear results and DNA amplification, demonstrating that microscopic analysis of blood smear is very unspecific with very low sensitivity when compared with PCR.

Several previously unrecognized or neglected vectorborne pathogens that affect companion animals are present in Latin America, and specifically, Argentina. The data presented here show that zoonotic pathogens of the genera Anaplasma, Babesia, Bartonella and Mycoplasma occur in variable prevalences in dogs without any visible sign of infection or clinical signs.

Unfortunately, vector-borne diseases are among the most complex of all infectious diseases to diagnose, mitigate, control and prevent. In this work, we presented evidence of several previously unreported infections in dogs from Argentina: Bartonella clarridgeiae, an uncharacterized Bartonella sp. (closely related to B. tribocorum), and three hemotropic Mycoplasma spp. (M. haematoparvum, M. haemocanis and M. suis).

\section{Conclusions}

Most if not all of the bacterial pathogens detected during this study are zoonotic [30-33], which not only represent risk for companion animals, but also for people. Unfortunately, the information about the importance and risks related to canine vector-borne pathogens available to veterinarians, public, and the medical community, is very scarce, limited, or simply inexistent. In that sense, to address the challenges that CVBD impose to the region, significant improvements in clinical diagnosis, medical practices, and vector control and surveillance, should be implemented.

\section{Abbreviations}

CVBD: Canine vector-borne diseases; EDTA: Ethylenediaminetetraacetic acid; PCR: Polymerase chain reaction

\section{Acknowledgement}

This paper has been sponsored by Bayer Animal Health in the framework of the 12th CVBD World Forum Symposium. The authors want to thanks Dr. Edward B. Breitschwerdt (Intracellular Pathogens Research Laboratory, Dept. of Clinical Sciences, College of Veterinary Medicine, North Carolina State University) for his support and contribution.

\section{Funding}

This work had been funded in part by the Intracellular Pathogens Research Laboratory, Dept. of Clinical Sciences, College of Veterinary Medicine, North Carolina State University.

Availability of data and materials Not applicable.

\section{Authors' contributions}

GPT and NBP performed the sample acquisition, as well as the clinical and blood smear testing, and blood DNA extraction. PEM and RGM performed the PCR testing of the patient samples, DNA sequencing, alignments, and the identification for each pathogen detected and their phylogenetic relationships. All authors read, contributed to and approved the intellectual content of the final version of this manuscript.

\section{Competing interests}

The authors declare that they have no competing interests.

\section{Consent for publication}

Not applicable.

\section{Ethics approval and consent to participate}

Sample acquisition was performed by GPT as part of his clinical work.

\section{Author details}

${ }^{1}$ Intracellular Pathogens Research Laboratory, Department of Clinical Sciences, College of Veterinary Medicine, North Carolina State University, 1060 Williams Moore Dr., Raleigh, NC 27607, USA. ²Cátedra de Microbiología, Facultad de Ciencias Veterinarias, Universidad Nacional de Rosario, Bv. Spangemberg and Bv. Colón, 2170 Casilda, Santa Fé, Argentina.

Received: 27 October 2016 Accepted: 28 November 2016

Published online: 15 December 2016

\section{References}

1. Eiras DF, Basabe J, Mesplet M, Schnittger L. First molecular characterization of Babesia vogeli in two naturally infected dogs of Buenos Aires, Argentina. Vet Parasitol. 2008;157:294-8.

2. Eiras DF, Craviotto MB, Vezzani D, Eyal O, Baneth G. First description of natural Ehrlichia canis and Anaplasma platys infections in dogs from Argentina. Comp Immunol Microbiol Infect Dis. 2013;36:169-73.

3. Eiras DF, Basabe J, Scodellaro CF, Banach DB, Matos ML, Krimer A, et al. First molecular characterization of canine hepatozoonosis in Argentina: evaluation of asymptomatic Hepatozoon canis infection in dogs from Buenos Aires. Vet Parasitol. 2007;149:275-9.

4. Vezzani D, Carbajo AE. Spatial and temporal transmission risk of Dirofilaria immitis in Argentina. Int J Parasitol. 2006;36:1463-72.

5. Vezzani D, Carbajo AE, Fontanarrosa MF, Scodellaro CF, Basabe J, Cangiano G, et al. Epidemiology of canine heartworm in its southern distribution limit in South America: risk factors, inter-annual trend and spatial patterns. Vet Parasitol. 2011;176:240-9.

6. Vezzani D, Eiras DF, Wisnivesky C. Dirofilariasis in Argentina: historical review and first report of Dirofilaria immitis in a natural mosquito population. Vet Parasitol. 2006:136:259-73.

7. Cuervo PF, Mera YSR, Waisman V, Gerbeno L, Sidoti L, Albonico F, et al. Detection of Dirofilaria immitis in mid-western arid Argentina. Acta Parasitol. 2013;58:612-4.

8. Padilla AM, Marco JD, Diosque P, Segura MA, Mora MC, Fernandez MM, et al. Canine infection and the possible role of dogs in the transmission of American tegumentary leishmaniosis in Salta, Argentina. Vet Parasitol. 2002;110:1-10.

9. Marco JD, Padilla AM, Diosque P, Fernandez MM, Malchiodi EL, Basombrio MA. Force of infection and evolution of lesions of canine tegumentary leishmaniasis in northwestern Argentina. Mem Inst Oswaldo Cruz. 2001;96:649-52.

10. Marco JD, Barroso PA, Calvopina M, Kumazawa H, Furuya M, Korenaga M, et al. Species assignation of Leishmania from human and canine American tegumentary leishmaniasis cases by multilocus enzyme electrophoresis in North Argentina. Am J Trop Med Hyg. 2005;72:606-11.

11. Cruz I, Acosta L, Gutierrez MN, Nieto J, Canavate C, Deschutter J, et al. A canine leishmaniasis pilot survey in an emerging focus of visceral leishmaniasis: Posadas (Misiones, Argentina). BMC Infect Dis. 2010;10:342.

12. Barroso PA, Nevot MC, Hoyos CL, Locatelli FM, Lauthier JJ, Ruybal P, et al. Genetic and clinical characterization of canine leishmaniasis caused by Leishmania (Leishmania) infantum in northeastern Argentina. Acta Trop. 2015;150:218-23.

13. Barroso PA, Marco JD, Locatelli FM, Cardozo RM, Hoyos CL, Mora MC, et al. Visceral leishmaniasis caused by Leishmania infantum in Salta, Argentina: possible reservoirs and vectors. Am J Trop Med Hyg. 2015;93:334-9. 
14. Acardi SA, Liotta DJ, Santini MS, Romagosa CM, Salomon OD. Detection of Leishmania infantum in naturally infected Lutzomyia longipalpis (Diptera: Psychodidae: Phlebotominae) and Canis familiaris in Misiones, Argentina: the first report of a PCR-RFLP and sequencing-based confirmation assay. Mem Inst Oswaldo Cruz. 2010;105:796-9.

15. Gould IT, Perner MS, Santini MS, Saavedra SB, Bezzi G, Maglianese MI, et al. Visceral leishmaniasis in Argentina. Cases notification and distribution of vectors (2006-2012). Medicina (B Aires). 2013;73:104-10.

16. Cardinal MV, Lauricella MA, Ceballos LA, Lanati L, Marcet PL, Levin MJ, et al. Molecular epidemiology of domestic and sylvatic Trypanosoma cruzi infection in rural northwestern Argentina. Int J Parasitol. 2008;38:1533-43.

17. Cardinal MV, Orozco MM, Enriquez GF, Ceballos LA, Gaspe MS, AlvaradoOtegui JA, et al. Heterogeneities in the ecoepidemiology of Trypanosoma cruzi infection in rural communities of the Argentinean Chaco. Am J Trop Med Hyg. 2014:90:1063-73.

18. Castanera MB, Lauricella MA, Chuit R, Gurtler RE. Evaluation of dogs as sentinels of the transmission of Trypanosoma cruzi in a rural area of northwestern Argentina. Ann Trop Med Parasitol. 1998;92:671-83.

19. Enriquez GF, Cardinal MV, Orozco MM, Schijman AG, Gurtler RE. Detection of Trypanosoma cruzi infection in naturally infected dogs and cats using serological, parasitological and molecular methods. Acta Trop. 2013;126:211-7.

20. Gurtler RE, Cecere MC, Lauricella MA, Cardinal MV, Kitron U, Cohen JE. Domestic dogs and cats as sources of Trypanosoma cruzi infection in rural northwestern Argentina. Parasitology. 2007:134:69-82.

21. Gurtler RE, Cecere MC, Petersen RM, Rubel DN, Schweigmann NJ. Chagas disease in north-west Argentina: association between Trypanosoma cruzi parasitaemia in dogs and cats and infection rates in domestic Triatoma infestans. Trans R Soc Trop Med Hyg. 1993;87:12-5.

22. Gurtler RE, Cecere MC, Rubel DN, Petersen RM, Schweigmann NJ, Lauricella MA, et al. Chagas disease in north-west Argentina: infected dogs as a risk factor for the domestic transmission of Trypanosoma cruzi. Trans R Soc Trop Med Hyg. 1991;85:741-5.

23. Petersen RM, Gurtler RE, Cecere MC, Rubel DN, Lauricella MA, Hansen D, et al. Association between nutritional indicators and infectivity of dogs seroreactive for Trypanosoma cruzi in a rural area of northwestern Argentina. Parasitol Res. 2001;87:208-14.

24. Cicuttin GL, Brambati DF, Rodriguez Eugui II, Lebrero CG, De Salvo MN, Beltran FJ, et al. Molecular characterization of Rickettsia massiliae and Anaplasma platys infecting Rhipicephalus sanguineus ticks and domestic dogs, Buenos Aires (Argentina). Ticks Tick Borne Dis. 2014;5:484-8.

25. Cicuttin GL, Vidal P, Nazarena De Salvo M, Beltran FJ, Gury Dohmen FE. Molecular detection of Rickettsia massiliae and Anaplasma platys infecting Rhipicephalus sanguineus ticks and dogs, Bahia Blanca (Argentina). Rev Chilena Infectol. 2014:31:563-8.

26. Tártara G, Pereyra N, Salvador F, González Beltrán S. Detección de estructuras compatibles con micoplasmas hemotróficos en extendidos sanguíneos de perros de la ciudad de Rosario. In: Revista veterinaria Argentina. 2013. p. 2.

27. Maggi RG, Birkenheuer AJ, Hegarty BC, Bradley JM, Levy MG, Breitschwerdt EB. Comparison of serological and molecular panels for diagnosis of vector-borne diseases in dogs. Parasit Vectors. 2014;7:127.

28. Dantas-Torres F. Canine vector-borne diseases in Brazil. Parasit Vectors. 2008;1:25.

29. de Caprariis D, Dantas-Torres F, Capelli G, Mencke N, Stanneck D, Breitschwerdt EB, et al. Evolution of clinical, haematological and biochemical findings in young dogs naturally infected by vector-borne pathogens. Vet Microbiol. 2011;149:206-12.

30. Maggi RG, Compton SM, Trull CL, Mascarelli PE, Mozayeni BR, Breitschwerdt EB. Infection with hemotropic Mycoplasma species in patients with or without extensive arthropod or animal contact. J Clin Microbiol. 2013;51: 3237-41.

31. Davenport AC, Mascarelli PE, Maggi RG, Breitschwerdt EB. Phylogenetic diversity of bacteria isolated from sick dogs using the BAPGM enrichment culture platform. J Vet Intern Med. 2013;27:854-61.

32. Diniz PP, Velho PE, Pitassi LH, Drummond MR, Lania BG, Barjas-Castro ML, et al. Risk factors for Bartonella species infection in blood donors from Southeas Brazil. PLoS Negl Trop Dis. 2016;10:e0004509.

33. Pitassi LH, de Paiva Diniz PP, Scorpio DG, Drummond MR, Lania BG, BarjasCastro ML, et al. Bartonella spp. bacteremia in blood donors from Campinas, Brazil. PLoS Negl Trop Dis. 2015;9:e0003467.

\section{Submit your next manuscript to BioMed Central and we will help you at every step:}

- We accept pre-submission inquiries

- Our selector tool helps you to find the most relevant journal

- We provide round the clock customer support

- Convenient online submission

- Thorough peer review

- Inclusion in PubMed and all major indexing services

- Maximum visibility for your research

Submit your manuscript at www.biomedcentral.com/submit
) Biomed Central 